\title{
Note on different kinds of attachments in trigonocarpalean (Medullosales) ovules from the Pennsylvanian Sydney Coalfield, Canada
}

\author{
ERWIN L. ZODROW \\ 503 Coxheath Road, Sydney, Nova Scotia, Canada B1P 6L2 <erwin_zodrow@uccb.ca> \\ Date received:April 16, 2004 I Date accepted:September 7, 2004
}

\begin{abstract}
The global data base for detached trigonocarpalean (Medullosales) ovules is large, and they are found in the Euramerican and Cathaysian floral provinces, from the Pennsylvanian to early Permian Periods. Despite the abundance, little is still known on what parts of the parent plant the ovules were borne, or in what arrangement they were attached. New data are presented for organically paired, suggested triplet, and axially or cauline borne trigonocarpalean ovules from the Sydney Coalfield, Nova Scotia.

\section{RÉSUMÉ}

La base de données mondiale des ovules trigonocarpaléens (Medullosales) détachés est imposante; on les trouve dans les provinces floristiques euraméricaine et cathaysienne de la période du Pennsylvanien au Permien précoce. Malgré cette abondance, on sait encore peu de choses sur les parties de la plante-mère où sont nés les ovules, ou selon quelle disposition ils étaient fixés. De nouvelles données sont présentées au sujet d'ovules trigonocarpaléens biologiquement jumelés, présumés triplets et axiaux ou caulinaires du terrain houiller de Sydney, en Nouvelle-Écosse.
\end{abstract}

[Traduit par la rédaction.]

\section{INTRODUCTION}

Ovules of three-fold, longitudinal division, or multiples thereof, known since the 1820 s, were systematically treated by Brongniart(summary: Gastaldo and Matten 1978). Commonly, these ovules are preserved either as compression/impression (Trigonocarpus Brongniart, 1828), some as coal-ball petrification, others in silicified peats (see Pachytesta Brongniart, 1874a, b), i.e., with three-dimensional structural preservation. It is recognized today that the genus Trigonocarpus is known from a number of different preservational stages and states of the biological ovule, and that some of these are correlative with the genus Pachytesta .

Bell (1938) mentioned the common association in the Sydney Coalfield between the $2-5$ cmlong ovule Schizospermum (Trigonocarpus) noeggerathii Brongniart and Macroneuropteris scheuchzeri (Hoffmann). However, he recorded $(1962,1969)$ no smaller or larger [medullosalean] ovules from the Sydney Coalfield, even though the present author collected the large ovules from nearly all of the coal seams (Table 1) from which Bell also had collected (compare Bell 1938, Fig. 1 of Zodrow and McCandlish 1980a, table 6).

Undisputedly organically connected medullosalean ovules are extremely rare in the Pennsylvanian-early Permian stratigraphic record. Only a handful have been documented to date. Of these, most are attached to fragmentary, ultimate pinnae (Halle 1927, 1933; Arnold 1937; Zodrow and McCandlish 1980 b) without pinnule replacement, or to fragmentary axes (Drinnan et al. 1990; Zodrow 2002). This note illustrates heretofore unknown ways in which ovules could have been borne by the medullosalean parent plant, based on mostly physical association.

\section{SAMPLE MATERIAL AND DEPOSITORY}

The study specimens are compression/impression-preserved and originated from the middle upper Westphalian D and basal Cantabrian strata of the Sydney Coalfield (Cleal et al. 2003). Accession numbers, i.e., 003(GF)-352, are cited, and the material is curated by the author as part of the Palaeobotanical Collections at the University College of Cape Breton, Sydney, Nova Scotia. 
Table 1. Summary of trigonocarpalean-ovule attachments, Sydney Coalfield, Nova Scotia (stratigraphic youngest to older coal seams).

\begin{tabular}{|c|c|c|c|c|c|}
\hline \multirow{2}{*}{$\begin{array}{l}\text { Accession \# } \\
998-359\end{array}$} & \multirow{2}{*}{$\begin{array}{c}\text { Coal Seam } \\
\text { Point Aconi }\end{array}$} & \multicolumn{2}{|c|}{$\begin{array}{l}\text { Length/Width } \\
\text { of ovule in } \mathrm{cm}^{\mathrm{a}}\end{array}$} & \multirow{2}{*}{$\begin{array}{c}\begin{array}{c}\text { Architecture/ } \\
\text { attachment of } \\
\text { ovules }\end{array} \\
\text { paired }\end{array}$} & \multirow[t]{2}{*}{ Medullosalean-floral association } \\
\hline & & 2.5 & 1.2 & & \\
\hline $985-281$ & Point Aconi & 4.5 & 2.0 & paired & $\begin{array}{l}\text { alethopterids, neuropterid, macroneuropterid, and single, } \\
\text { detached ovules }\end{array}$ \\
\hline 003-352 & Unnamed & 2.5 & 2.0 & paired & $\begin{array}{l}\text { Macroneuropteris scheuchzeri, medullosalean axes, and detached } \\
\text { morphologically similar ovules }\end{array}$ \\
\hline $002-213^{b}$ & Lloyd Cove & $10-11$ & $4-5$ & axial & $\begin{array}{l}\text { Alethopteris zeilleri, medullosalean axes, and single, detached } \\
\text { ovules }\end{array}$ \\
\hline 002-339 & Lloyd Cove & 8.0 & 4.0 & single, cauline? & A. zeilleri, medullosalean axes, and single, detached ovules \\
\hline $004-263$ & Lloyd Cove & 9.0 & 4.0 & single, cauline? & A. zeilleri, medullosalean axes, and single, detached ovules \\
\hline 985-202 & Stubbart & 5.7 & 4.0 & single, cauline? & Alethopteris sp., Linopteris obliqua \\
\hline $977-737^{\mathrm{c}}$ & Harbour & 1.1 & 0.5 & single rachial & $\begin{array}{l}\text { Mixed, neuropterids, macroneuropterids, and single, detached } \\
\text { ovules }\end{array}$ \\
\hline $004-238$ & Collins & 4.5 & 2.5 & cluster of three & Mostly Alethopteris ambigua \\
\hline
\end{tabular}

${ }^{a}$ See text. ${ }^{b}$ Zodrow (2002, Fig. 16a) ${ }^{c}$ Zodrow and McCandlish (1980b)

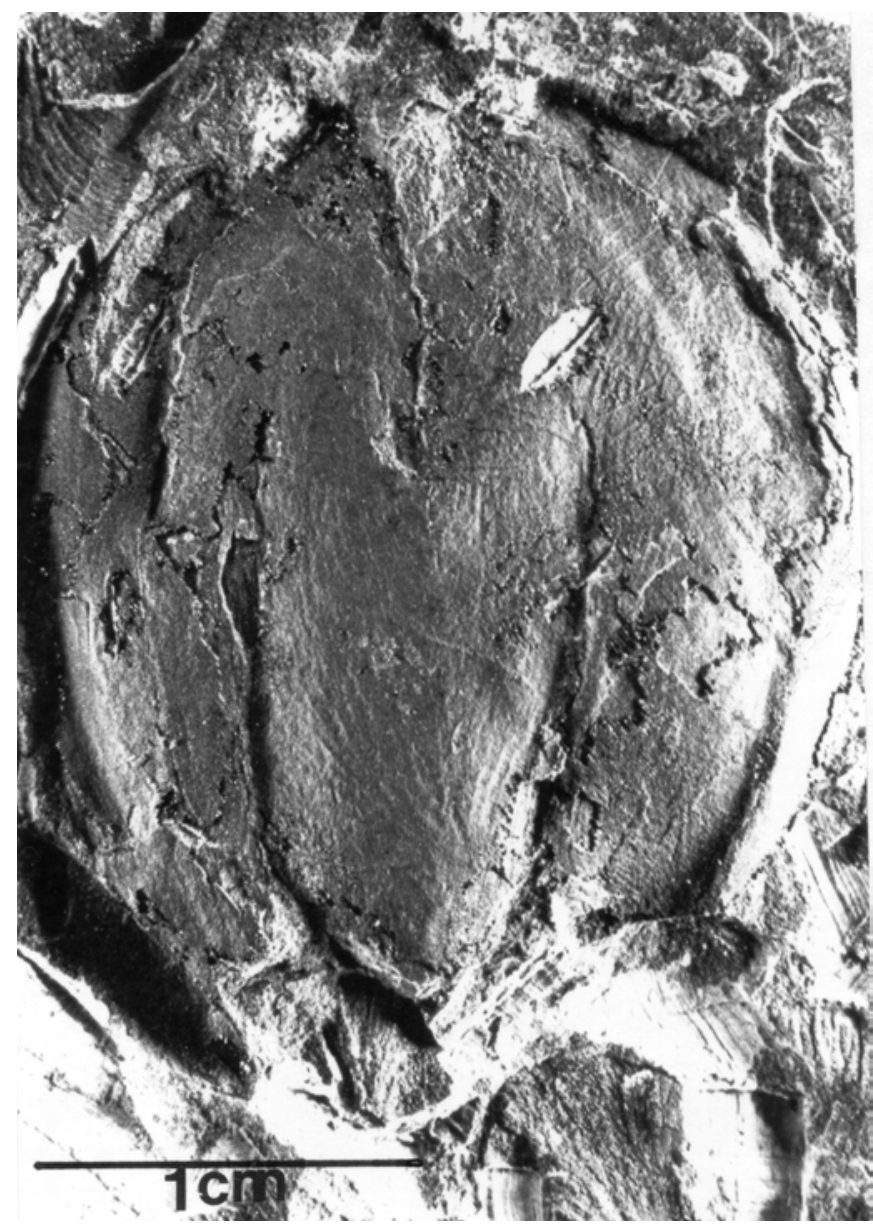

\section{SUMMARY DESCRIPTION}

Canada's largest ovular medullosalean collection contains over one hundred trigonocarpalean specimens that have been collected by the author from the Sydney Coalfield, Canada, since 1974. This would make it one of the rarest fossil collections, when compared with the ca. 15000 specimen collections from Sydney. These ovules either show commissural compression/impressions (e.g., Fig. 1), or longitudinal primary and secondary ribbing from end to end (e.g., Fig. 6), and range in length from 1-12 cm and in width from 0.5-4.5 $\mathrm{cm}$. The smallest $1 \mathrm{~cm}$ long ovules, preserved as the sclerotesta (see Halle, 1927), are associated with, or in organic connection with Neuropteris flexuosa Sternberg (Zodrow and McCandlish 1980b) which is shown in Fig. 2. The record shows at least another 10 of these 'nut-like' ovules are physically associated with $N$. flexuosa foliage from the same stratigraphic locality. The largest, $12 \mathrm{~cm}$ long ovules show arrangement of secondary ribs along the entire length of the ovule most comparable with Pachytesta incrassata Brongniart. Undoubtedly, additional species wait to be identified in the Palaeobotanical Collections.

Approximately $10 \%$ of the ovular specimens collected are physically or organically connected with certain parts of

Fig. 1 Trigonocarpus sp. 977-737; detached ovule, illustrating two well- preserved major commissural ribs in the distal part. Lingan Mine (now closed), Harbour Seam, Sydney Coalfield, Canada (in litteris Prof. W. Stewart, January 9, 1978). 
fragmentary plant parts (Table 1). These extremely rare finds are recorded from the mid Westphalian D to basal Cantabrian stages (Point Aconi to Collins seams), and include:

998-359 Trigonocarpus sp. Fig. 3; paired ovules, not attached to the parent plant, with exposed one or two commissural ribs in the distal part. A sub-millimetre coalified layer forms the outer part. Careful dégaging did not reveal organic ovular connection.

985-281 Trigonocarpus sp.; paired ovules, not attached to the parent plant, slender, with exposed one or two commissural ribs or ribbing along the entire length. Organic connection could not be confirmed from the preservation.

003-352 Trigonocarpus sp., Figs. 4 and 5A; organically paired ovules, not attached to the parent plant. At least two thin, surfically structureless, coalified layers, separated by sediments, are visible under the microscope. Organic connection with the $6 \mathrm{~mm}$ wide and $3.5 \mathrm{~cm}$ stalk could not be confirmed. This pair of ovules is associated with very abundant foliage of $M$. scheuchzeri (Hoffmann) over a $40 \mathrm{~cm}$ thick shale bed in the basal Cantabrian.
003-213 Pachytesta incrassata Brongniart (Fig. 5B); three ribbed ovules singly aligned along an axis (Zodrow 2002, Fig. 16a), and associated with abundant foliage of Alethopteris zeilleri (Ragot). Organic connection to an axis is probable, but not confirmed.

002-339 Pachytesta incrassate Brongniart (Figs. 5C and 6); three single, ribbed ovules in physical connection at the margin of an axis. It is preserved for a length of $24 \mathrm{~cm}$ and a width of $8 \mathrm{~cm}$, and shows continuous longitudinal ridges or striae. The width of the axis is consistent with measurements of cauline specimens reported by Zodrow (2002). The specimen originated from the stratigraphical level above the Lloyd Cove Seam that preserved a great abundance of foliage of Alethopteris zeilleri (Ragot).

004-263 Pachytesta incrassata Brongniart; one single, ribbed ovule in physical connection at the margin of an axis that is preserved for a length of $23 \mathrm{~cm}$, minimal width of $5 \mathrm{~cm}$, and ridged or striated the same as the above specimen is. From the same location as 002-339.

985-202 Pachytesta sp. aff. incrassata Brongniart (Fig. 7), a single, ribbed ovule with three identifiable coalified layers

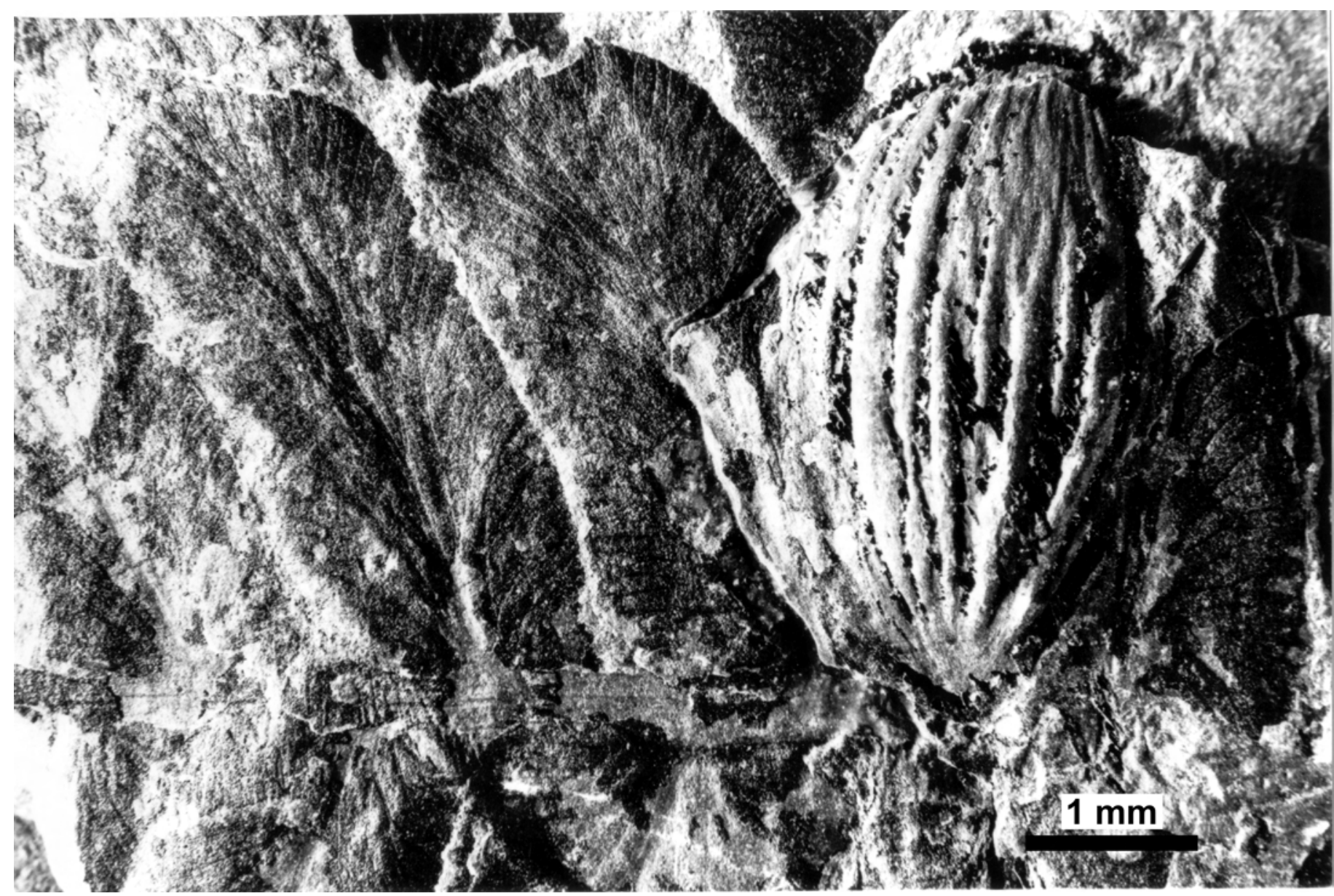

Fig. 2 Trigonocarpus sp., 977-737a; sclerotesta organically connected with Neuropteris flexuosa Sternberg (Zodrow and McCandlish 1980b). 


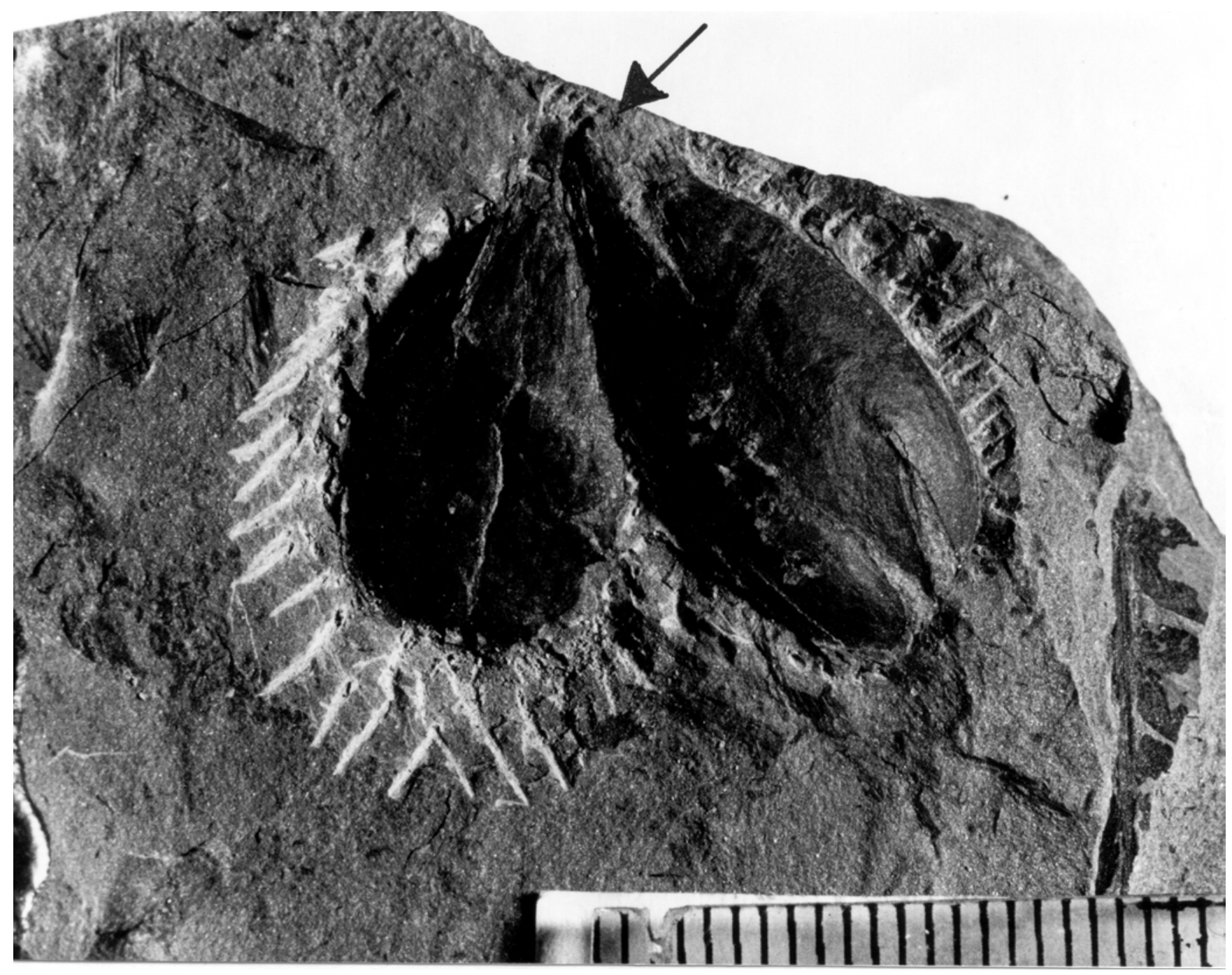

Fig. 3 Trigonocarpus sp.; paired ovules with distal commissural ribs. Arrow points to assumed location of organic connection between the two ovules.

that are separated from each other by very thin shaley layers. The ovule is physically connected at the margin. The axis, preserved for a length of $17 \mathrm{~cm}$ and a width of $4 \mathrm{~cm}$, is ridged and striated (the same way as those in 004-263 and 02-339). Associated with abundant foliage of Alethopteris sp. in the Prince Mine (closed).

977-737a Trigonocarpus sp. (Figs. 2 and 5D): single, ribbed ovule organically connected to an ultimate rachis without replacing a pinnule of Neuropteris flexuosa Sternberg. The sclerotesta is preserved (Zodrow and McCandlish 1980b).

04-238 Trigonocarpus sp. (Figs. 5E, F and 8): three ribbed ovules physically connected with one another. The large, ribbed ovule is differently preserved from the two on the right in the sense that each of the latter shows two very thin coalified layers separated by ?sediments.

The preserved ridges and striations in specimens 002-339, 004-263, and 985-202 represent impressed cortical sclerenchy- matous fibres or bundles in support of medullosalean axes or stems (see Zodrow 2002). Also, the separated coalified layers, particularly prevalent in the $P$. incrassata specimens, probably represent [presently unidentifiable] internal biological structures in the ovules.

\section{CONCLUSION}

The upper part of the Sydney Coalfield continues to furnish novel data that permit the conclusion that much greater attachment diversity existed in the trigonocarpaleans than previously thought. It is also noted that three-dimensionally preserved ovular casts were not found.

With respect to Stephanspernum konopeonus, Drinnan et al. (1990) raised the important question about cauline-borne ovules for pteridosperms. The best approximation in answer to their question is as yet supplied by the three cauline specimens described. This leaves unanswered, however, the question if 


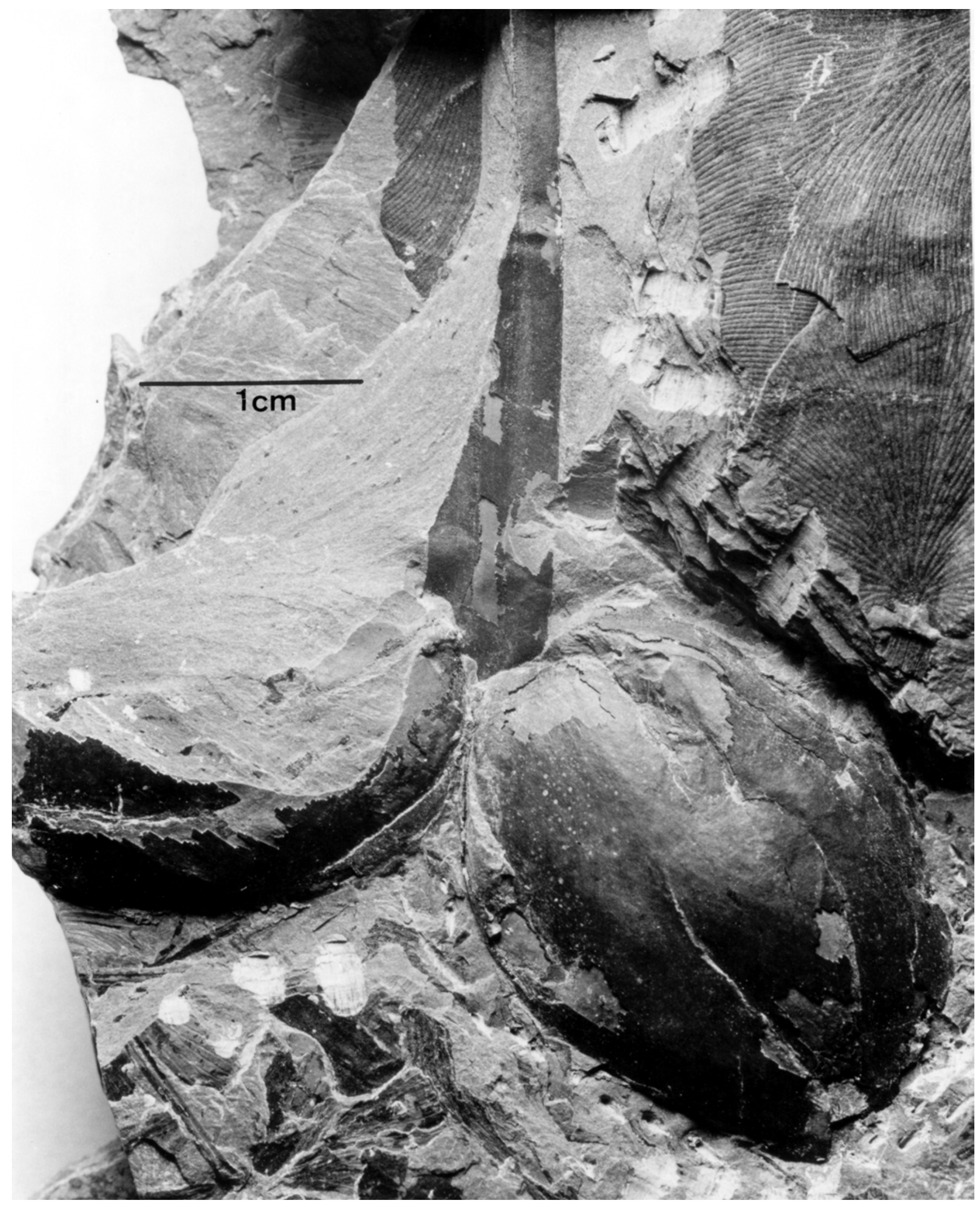

Fig. 4 Trigonocarpus sp. 003-352; organically paired, stalked? ovules associated with Macroneuropteris scheuchzeri (upper right-hand corner) and "Odontopteris subcuneata" (=M. scheuchzeri), lower left-hand corner. 

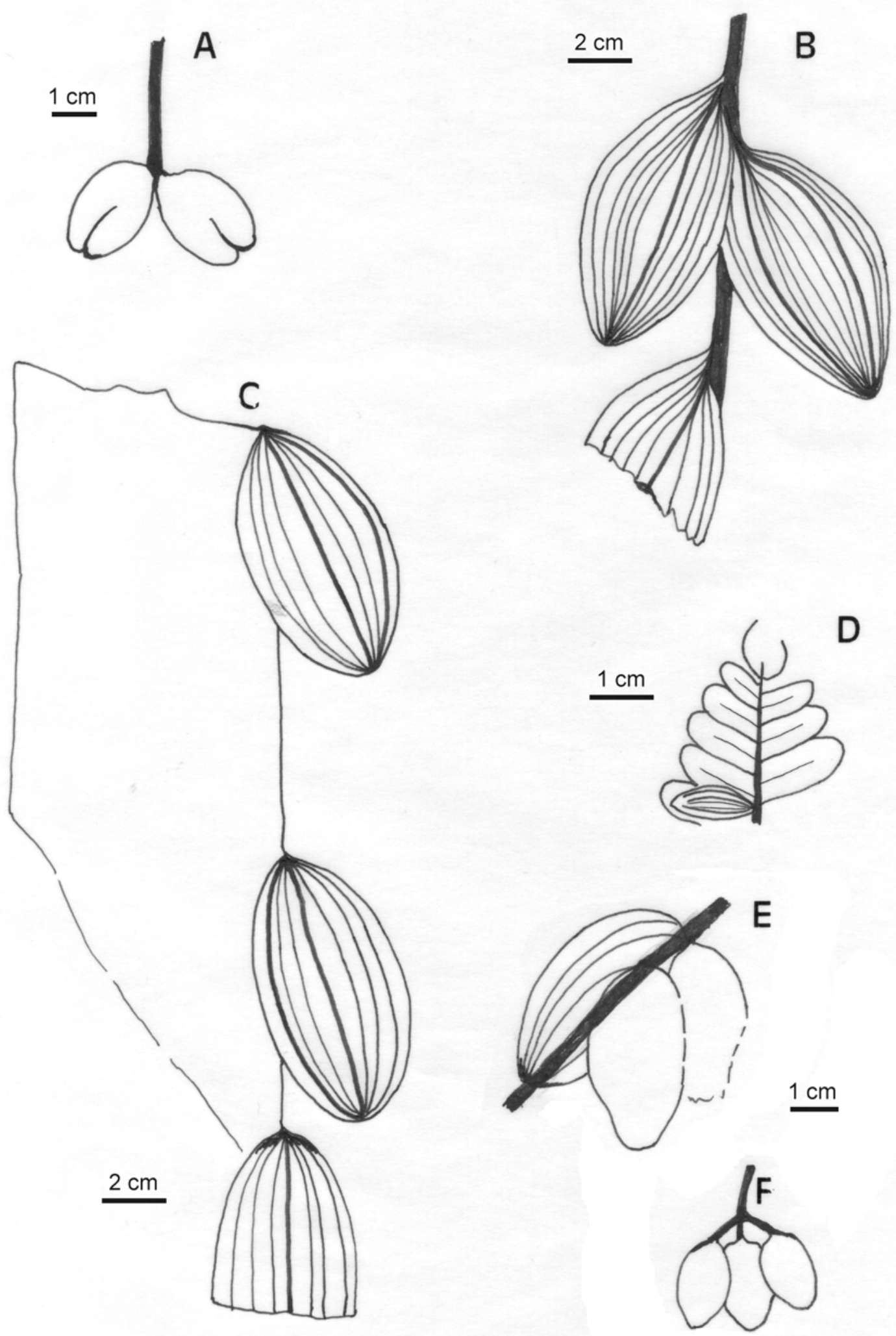

Fig. 5 Hand-drawn presentation from photographs. Interpretations of attachment of medullosalean ovules, Sydney Coalfield, Canada. (A) Trigonocarpus sp., 003-352; stalked, organically paired ovules. (B) Pachytesta incrassata Brongniart, 002-213; axially attached ovules (Zodrow 2002, Fig. 16a). (C) Pachytesta incrassata, 002-339; cauline-attached ovules. (D) Trigonocarpus sp., 977-737a; organically attached to Neuropteris flexuosa Sternberg (Zodrow and McCandlish 1980b). (E) Pachytesta sp., 004-238; cluster of three ovules attached to an axis. (F) Alternative interpretation of (E) as trichomous branching. 


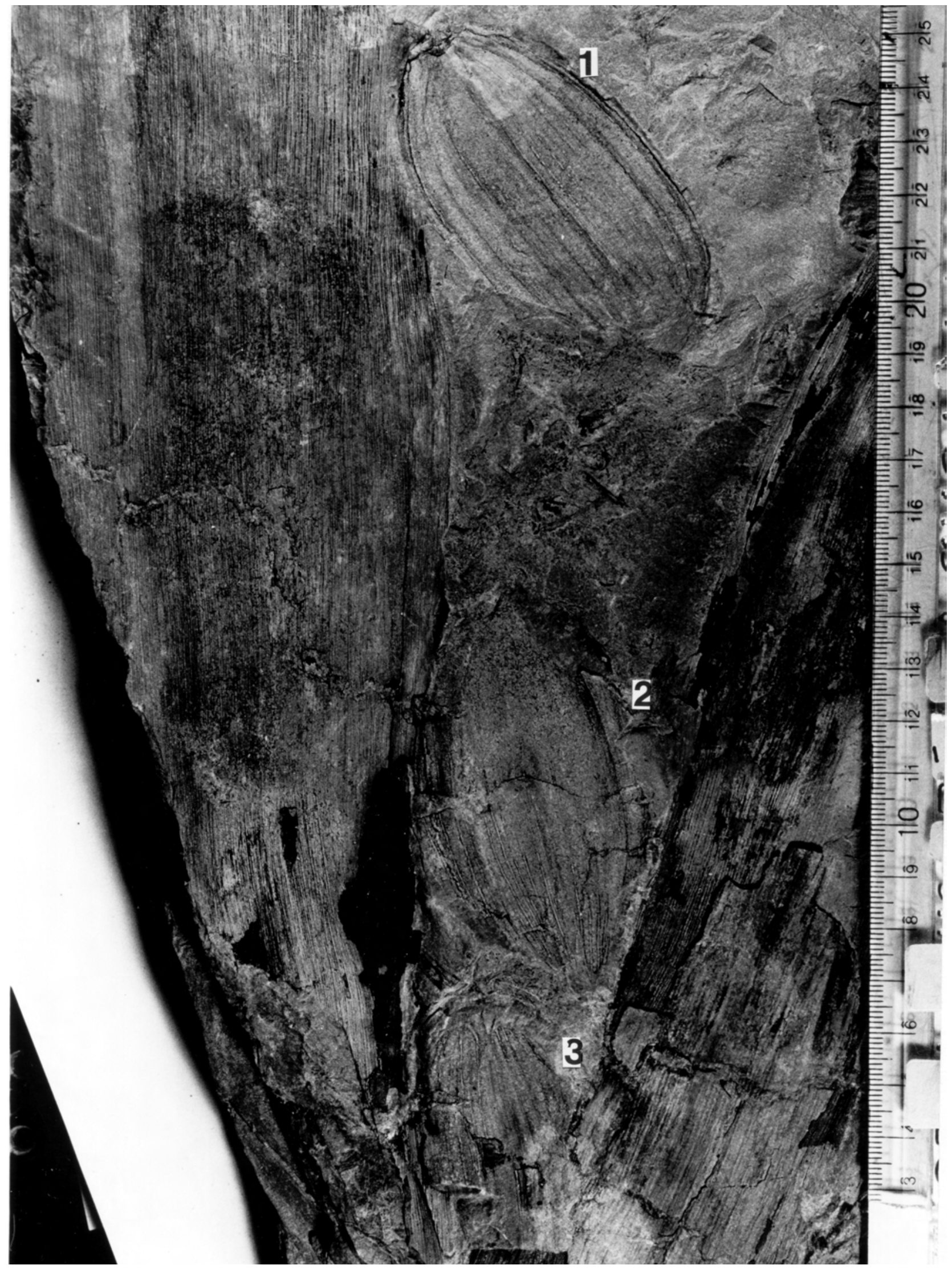

Fig.6 Pachytesta incrassata Brongniart, 002-339; three $(1,2,3)$ ovules physically aligned along the margin of a medullosalean stem. Organic connection could not be demonstrated 


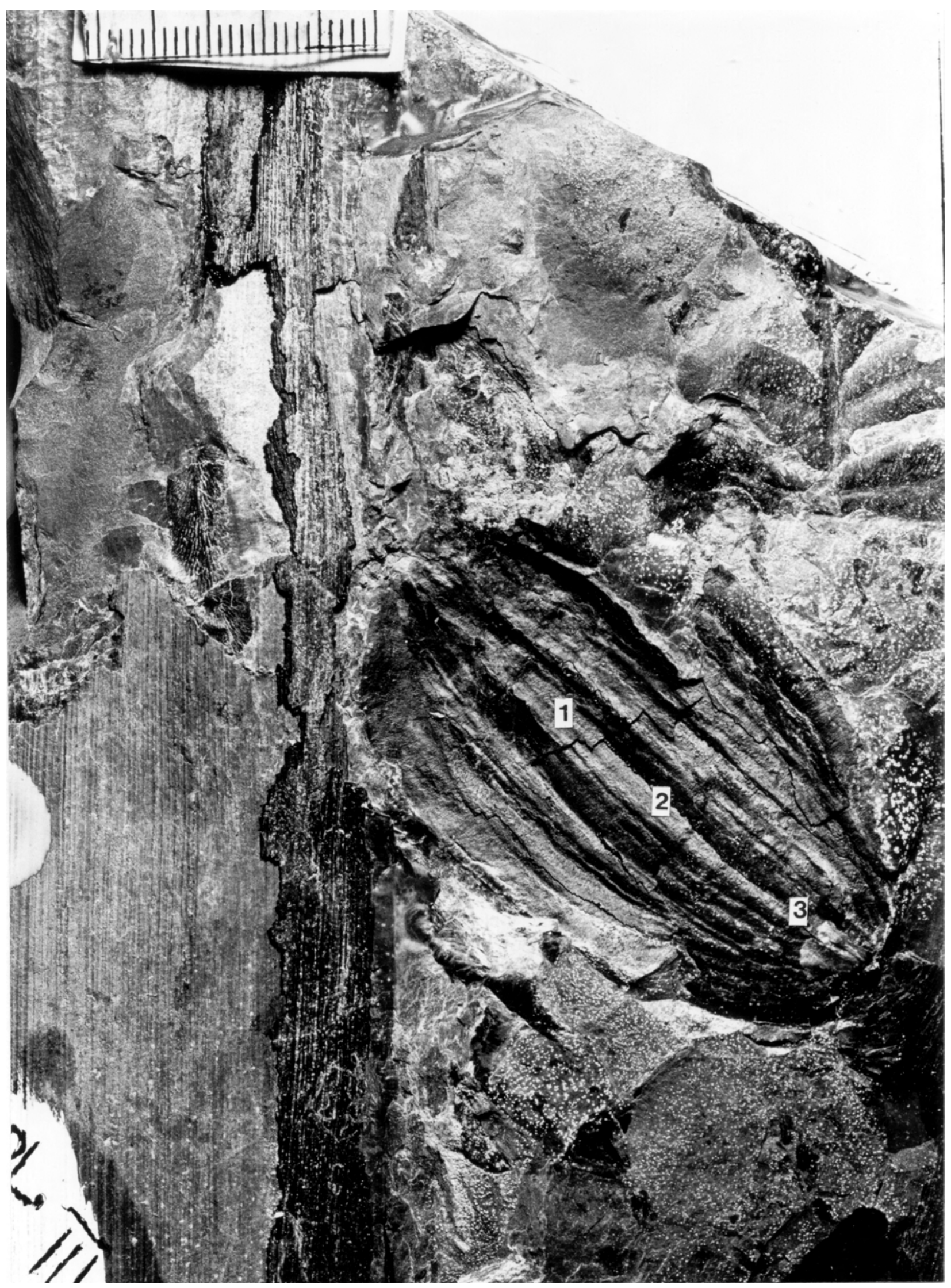

Fig. 7 Pachytesta sp. aff. incrassata Brongniart, 985-202; the ovule shows three $(1,2,3)$ definitive coalified layers, and it is physically aligned with a medullosalean axis. Organic connection could not be demonstrated. 


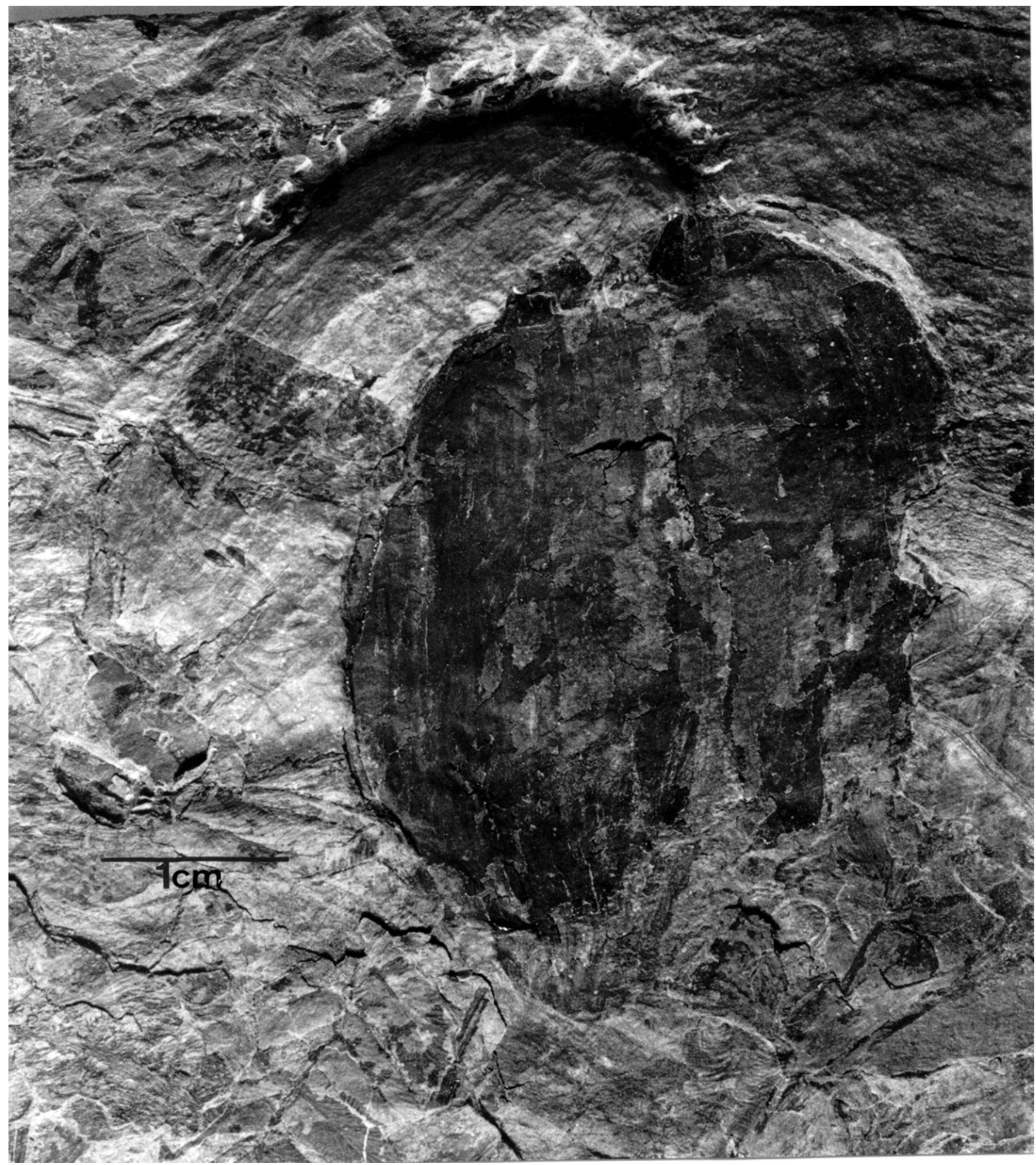

Fig. 8 Pachytesta sp. 004-238; three ovules in physical connection with each other. 
cauline attachment was by single or paired ovules, or by an as yet unknown number of ovules positioned along margins of an ?axis. Moreover, paired or axially-borne ovules could represent a modified reproductive frond structure.

Dimensional measurements of compression/impression ovules (Table 1) are preservation-biased, which suggests not to use them as a basis for biological-species delineation.

Although still based on circumstantial evidence, it is suggested that paired trigonocarpalean ovules are a fructification structure of $M$. scheuchzeri agreeing with Bell(1938) in regards to the same genus Trigonocarpus.

Furthermore, it is interesting to consider if neuropterids are separable from alethopterids alone on the grounds of different ovular attachments, with ramification in taxonomy.

\section{ACKNOWLEDGEMENTS}

I am grateful to journal reviewers C.J. Cleal, National Museum and Galleries of Wales, Cardiff, and J. Hilton, Cardiff University, for additional literature and challenging suggestions that helped improve style and content of the manuscript. Realization of this study is solely due to benevolent funding by the Natural Science and Engineering Research Council of Canada. The author is grateful for such support.

\section{REFERENCES}

Arnold, C.A. 1937. The seeds of Alethopteris, and other pteridosperms from North America. Deuxième Congrès l'avancement des études de strastigraphie Carbonifère. Compte rendu 1, pp. 41-45.

BELL, W.A. 1938. Fossil flora of Sydney Coal Field, Nova Scotia. Geological Survey of Canada, Memoir 215, 334 p.

BELL, W.A. 1962. Catalogue of types and figured specimens of fossil plants in the Geological Survey of Canada Collections. Geological Survey of Canada, $154 \mathrm{p}$.

BELL, W.A. 1969. Catalogue of types and figured specimens of fossil plants in the Geological Survey of Canada Collections (Megaplant supplement 1963-67). Geological Survey of Canada, $36 \mathrm{p}$.
Brongniart, A. 1828. Prodrome d'une histoire des végétaux fossiles. Dictionnaire des Sciences Naturelles, $223 \mathrm{p}$.

Brongniart, A. 1874a. Étude sur les graines fossiles trouvées a l'état silicifié dans le terrain houiller de Saint-Étienne. Deux. Partie. Compte rendu, Academie des Sciences, 79, pp. 427-435.

BrongNiART, A. 1874b. Étude sur les graines fossiles trouvées a l'état silicifié dans le terrain houiller de Saint-Étienne. Annales des Sciences Naturelle (Botanique), 20, pp. 234-260.

Cleal, C.J., Dikmitrova, T.Kh., \& Zodrow, E.L. 2003. Macrofloral and palynological criteria for recognizing the Westphalian-Stephanian boundary. Newsletter on Stratigraphy, 39, pp. 181-208.

Drinnan, A. N., Schramke, J. M., \& Crane, P. R. 1990. Stephanospermum konopeonus (Langford) comb. nov: a medullosan ovule from the Middle Pennsylvanian Mazon Creek flora of northeastern Illinois, U.S.A. Botanical Gazette, 151, pp. 385-401.

Gastaldo, R.A., \& Matten, L.C. 1978. Trigonocarpusleeanus, a new species from the Middle Pennsylvanian of southern Illinois. American Journal of Botany, 65, pp. 882-890.

Halle, T.G. 1927. Palaeozoic plants from Central Shansi. In Palaeontologia Sinica. Edited by V.K. Ting \& W.H. Wong, Geological Survey of China, Peking, 309 p. pls. 1-64.

Halle, T.G. 1933. The structure of certain fossil spore-bearing organs believed to belong to the pteridosperms. Kung. Svenska Vetenskapsakdemiens Handlingar, 12, pp. 1-103.

Zodrow, E.L. 2002. The "medullosalean forest" at the Lloyd Cove Seam (Pennsylvanian, Sydney Coalfield, Nova Scotia). Atlantic Geology, 38, pp. 177-195.

Zodrow, E.L. 2003. Foliar forms of Macroneuropteris scheuchzeri (Pennsylvanian, Sydney Coalfield, Nova Scotia, Canada). Atlantic Geology, 39, pp. 39-37. [not referenced]

Zodrow, E.L., \& McCandlish, K. 1980a. Upper Carboniferous fossil flora of Nova Scotia. Nova Scotia Museum, Halifax, 275 p.

Zodrow, E.L., \& McCANDLISH, K. 1980b. On a Trigonocarpus species attached to Neuropteris (Mixoneura) flexuosa from Sydney Coalfield, Cape Breton Island, Nova Scotia, Canada. Review of Palaeobotany and Palynology, 30, pp. 57-66.

Editorial responsibility: Ron K. Pickerill 